\title{
PENERAPAN MEMBACA KREATIF DALAM KETERAMPILAN BERCERITA PESERTA DIDIK
}

\author{
Aprilia Dwi Andini ${ }^{1}$, Triman Juniarso ${ }^{2}$, Ida Sulistyawati ${ }^{3}$ \\ Prodi Pendidikan Guru Sekolah Dasar, Universitas PGRI AdiBuana Surabaya, Surabaya, Indonesia. \\ Apriliaandini796@gmail.com, Trimanunipa@gmail.com, ida@unipasby.ac.id
}

\begin{tabular}{|c|c|}
\hline Informasi Artikel & Abstract \\
\hline Kata Kunci: & $\begin{array}{l}\text { Penelitian ini bertujuan untuk (1) menjelaskan proses Penerapan Membaca } \\
\text { Kreatif dalam Keterampilan Cerita }(2) \text { mendeskripsikan hasil penerapan }\end{array}$ \\
\hline Membaca Kreatif, & berupa tes hasil keterampilan bercerita dan tanggapan siswa terhadap \\
\hline $\begin{array}{l}\text { Keterampilan } \\
\text { Mendongeng, }\end{array}$ & $\begin{array}{l}\text { penerapan keterampilan membaca kreatif dalam keterampilan cerita Tema } 4 \\
\text { Subtema } 1 \text { Pembelajaran } 2 \text { Kelas III SDN Sedati Gede II Sidoarjo. Metode } \\
\text { deskriptif kuantitatif dengan memadukan metode kualitatif dan kuantitatif. }\end{array}$ \\
\hline Sekolah dasar & $\begin{array}{l}\text { Sampel data dalam penelitian ini adalah siswa kelas III-C yang berjumlah } 32 \\
\text { siswa. Teknik pengumpulan data yang digunakan adalah, observasi, tes dan } \\
\text { angket respon siswa. Kemudian teknik analisis data pertama menggunakan }\end{array}$ \\
\hline Diterima: 24-09-2020 & analisis data deskriptif kualitatif untuk menjelaskan penerapan membaca \\
\hline Disetujui: 07-10-2020 & $\begin{array}{l}\text { kreatif dalam keterampilan mendongeng. Teknik kedua menggunakan } \\
\text { analisis data deskriptif kuantitatif untuk menampilkan data hasil }\end{array}$ \\
\hline Dipubikasikan:25-11-2020 & $\begin{array}{l}\text { keterampilan bercerita dan tanggapan siswa. Hasil yang diperoleh (1) proses } \\
\text { penerapan keterampilan membaca kreatif dalam mendongeng dapat } \\
\text { diketahui aktivitas pendidik dan siswa telah dilakukan dengan sangat baik. } \\
\text { (2) Hasil tes keterampilan cerita penerapan diperoleh ketuntasan klasikal } \\
\text { dengan kategori "Baik". Sedangkan untuk respon siswa diperoleh hasil } \\
\text { dengan kategori "Sangat Baik". }\end{array}$ \\
\hline
\end{tabular}

\section{PENDAHULUAN}

Pendidikan merupakan suatu kegiatan yang dilakukan oleh manusia secara sadar, sistematis, terarah serta mengembangkan kemampuan agar kualitas kehidupan menjadi lebih baik. Pendidikan sekolah dasar menjadi awal dalam peningkatan kualitas sumber daya manusia (Rachmadtullah et al. 2020). Sehubungan dengan hal tersebut, sebagaimana tercantum pada Undang-Undang No. 20 Tahun 2003 bahwa "Pendidikan dasar merupakan jenjang pendidikan yang melandasi jenjang pendidikan menengah". Hal ini berarti bahwa pendidikan di sekolah dasar dirancang memenuhi tujuan kehidupan di masa depan. Pada jenjang sekolah dasar terdapat sejumlah mata pelajaran yang wajib dipelajari salah satunya ialah pelajaran bahasa indonesia. Muatan bahasa indonesia terdapat disemua tingkatan pendidikan Termasuk di sekolah dasar (SD). Pembelajaran bahasa indonesia memiliki tujuan agar siswa memahami keterampilan bahasa beserta kegunaanya. Bidang ilmu bahasa indonesia disekolah memiliki durasi yang cukup. Pada pengkajian 
disiplin ilmu bahasa. Menelaah keseluruhan aspek berbahasa. Semuanya bertujuan menginterpretasikan gagasan, pandangan dan pengalaman melalui verbal maupun non verbal.

Penataran bahasa di sekolah dasar memegang kedudukan yang sangat vital bagi peserta didik untuk mewujudkan kompetensi, kualifikasi dan attitude bagi kemajuanya. Dan juga pengkajian bahasa wajib mengelaborasikan kapabilitas bahasa krusial, tidak saja korespondensi tetapi menafsirkan kuantitas kognitif yang dipelajari. Dilihat dari cakupan materi dalam edukasi berbahasa indonesia. Kepiawaian berbicara memiliki kapasitas yang penting dalam meningkatkan keaktifan dan kemampuan peserta didik dalam berkomunikasi. Keterampilan berbicara merupakan keterampilan yang harus dikuasai oleh peserta didik di sekolah dasar, namun banyak dari peserta didik yang belum mampu mengolah keterampilan berbicaranya dengan baik. Oleh karena itu perlu dikembangkan aspek keterampilan berbicara. Keterampilan berbicara mendidik peserta didik agar sejak dini menanamkan sikap berani berbicara menyuarakan argumentasinya didepan umum dengan memperhatikan attitude berbahasa (Sari et al. 2020). Penjabaran keterampilan berbicara pada anak didik memfokuskan dalam kelancaran pelafalan, intonasi, dan ekspresi. Keterampilan berbicara untuk membentuk generasi penerus bangsa berjiwa pancasila yang tercermin melalui perilakunya yang mampu mengekspresikan perasaanya secara cerdas sesuai situasi pada saat berbicara. kreatif terampil berbicara dengan jelas, runtut, mudah dipahami. berbicara secara kritis memiliki efisiensi menafsirkan gagasan pengetahuan dan pandangan orang lain dengan baik. Menurut vygotsky (dalam aisyah, 2007:6) Berbicara adalah sentral yang penting dalam proses pembelajaran. Beliau berpendapat kemajuan bicara berkaitan langsung dengan kognitif seorang anak tersebut. Sehingga dapat disimpulkan semakin lamban anak untuk memulai berbicara maka kognitif anak tersebut semakin rendah. Manusia menyimbolkan dunia menggunakan ucapan saat berbicara. Oleh karena itu bicara merupakan cara menggambarkan dengan siapa kita berkomunikasi atau antar budaya negara lain.

Namun dilihat dari pentingnya kemampuan berbahasa tersebut, justru berbanding terbalik dengan kemampuan berbahasa anak indonesia dalam survey yang dilakukan Oleh The International Association For The Evaluation Of Educational Acbievement (IEA) Pada Tahun 2004 perihal kompetensi baca tulis anak-anak indonesia siswa SD kelas VI di enam provinsi daerah binaan primary project (PEQIP) kurang lebih 50\% tidak bisa bercerita. Sehubungan dengan hal tersebut, berdasarkan hasil pengamatan yang saya lihat kebanyakan peserta didik saat mengikuti bidang studi bahasa indonesia khususnya keterampilan bercerita, kebanyakan peserta didik banyak yang kurang paham terhadap cerita yang ia sampaikan, dari bahasa dan isi cerita banyak yang tidak tersampaikan dengan baik dan tepat, kurang mengekspresikan ceritanya banyak yang malu dan gugup saat bercerita didepan secara langsung dengan mmenatap audien atau teman-temanya dan beberapa siswa lainya seolah-olah menatap ke segala arah ketika diminta untuk bercerita. Kondisi ini tidak sesuai dengan tujuan pembelajaran, bilamana mayoritas anak didik mendapatkan KKM (Kriteria Ketuntasan Minimal). Parameter kompetensi bercerita peserta didik diantaranya adalah penampilan, bahasa, dan isi cerita yang disampaikan. 
Dari permasalahan tersebut maka perlu dilakukan perbaikan pembelajaran dalam keterampilan bercerita, perbaikan pembelajaran tersebut dapat dilakukan dengan menerapkan cara membaca kreatif yang merupakan proses membaca untuk mendapatkan pengetahuan dari apa yang dibacanya termasuk memunculkan ide-ide baru yang dapat dikembangkan atau dapat disimpulkan isi dari bacaanya, maka orang tersebut dapat dikatakan sebagai pembaca kreatif. Dengan demikian peserta didik dapat memahami suatu cerita dan dapat mencakup indikator dalam keterampilan bercerita. Berlandaskan kondisi permasalahan yang di deskripsikan penulis terdorong mengkaji implementasi membaca kreatif dalam keterampilan bercerita.

\section{METODE}

Metode kuantitatif deskriptif merupakan prosedur ilmiah yang faktual, logis, terstruktur, dan mempunyai tolok ukur. "Metode ini disebut metode kuantitatif dikarenakan data dari penelitian berupa angka-angka dan dianalisis"(Sugiyono, 2016:30).

Berdasarkan pandangan tersebut dapat disimpulkan kuantitatif deskriptif digunakan untuk mendeskripsikan kejadian atau peristiwa secara aktual dan konkret. Peneliti akan meneliti berbagai hal diantaranya aktivitas guru dan aktivitas siswa dalam proses penerapan membaca kreatif dan hasil tes keterampilan bercerita.

Metode kuantitatif deskriptif digunakan untuk mengumpulkan data penerapan membaca kreatif dalam keterampilan bercerita tahun pelajaran 2019/2020. Riset berlokasi di Sekolah Dasar Negeri Sedati Gede II Sidoarjo. Dengan populasi pelajar tingkat III Sekolah Dasar Negeri Sedati Gede II Sidoarjo, dan sampel seluruh peserta didik kelas III-C, sebanyak 32 peserta didik. Peneliti menggunakan teknik pengumpulan data yakni observasi, tes dan angket.

Instrument dalam penelitian yakni lembar observasi aktivitas pendidik dan peserta didik, lembar tes keterampilan bercerita untuk mengukur keterampilan bercerita peserta didik, kemudian lembar angket yang ditujukan untuk melihat respon ketertarikan siswa selama penelaahan dengan mengimplementasikan membaca kreatif.

Teknik analisis data yang digunakan ialah data kualitatif selama akumulasi data observasi. Tes tindakan keterampilan bercerita serta respon minat diakumulasikan secara kuantitatif.

\section{HASIL DAN PEMBAHASAN}

Penerapan membaca kreatif menghasilkan sebuah data kualitatif dan kuantitatif. Dimana data kuantitatif diperoleh melalui observasi sedangkan data kuantitatif didapatkan dengan tes unjuk kerja dan angket respon peserta didik.

Hasil aktualisasi observasi saat proses penerapan membaca kreatif didapatkan bahwasanya aktivitas penerapan membaca kreatif yang dilaksanakan oleh pendidik terlaksana sebesar 94,7\% dengan kategori 
"Sangat Baik". Sedangkan kegiatan penerapan membaca kreatif yang dilaksanakan oleh siswa tercapai sebesar $88,88 \%$ dengan klasifikasi "Sangat Baik".

Hasil penerapan berupa hasil tes keterampilan bercerita, sewaktu tahap penelaahan diperoleh dengan keterlaksanaan baik dan respon positif, hasil tes keterampilan bercerita peserta didik didapatkan dengan ketuntasan klasikal 75\% dan ketidak tuntasan 25\%.

Kemudian didapatkan hasil respon peserta didik memperoleh persentase 90,05\% dengan kategori "Sangat Baik". Hal ini menunjukan bahwa penerapan membaca kreatif dalam keterampilan bercerita membawa respon positif. Pembahasan mengenai proses dan hasil penerapan membaca kreatif dijabarkan sebagai berikut:

\section{Proses Penerapan}

Analisis kualitatif deskriptif digunakan peneliti untuk menguraikan pertanyaan pada rumusan masalah yang pertama yakni bagaimana proses penerapan membaca kreatif dalam keterampilan bercerita tahun pelajaran 2019/2020?.

Secara garis besar langkah-langkah membaca kreatif dalam keterampilan bercerita telah terlaksanan dengan sangat baik. Keseluruhan kegiatan selama proses proses pembelajaran sudah berfokus dan menitik beratkan terhadap peserta didik. Oleh sebab itu peserta didik menjadi lebih aktif selama proses pembelajaran dan pengetahuan yang didapatkan akan bertahan lama.

\section{Hasil Penerapan}

Implementasi membaca kreatif dalam keterampilan bercerita didapatkan dua hasil yakni yang pertama hasil tes keterampilan bercerita dan kedua hasil angket minat peserta didik. Hasil tes keterampilan bercerita pada bidang pengetahuan bahasa indonesia dapat dikatakan berhasil. Hal ini berdasarkan kemampuan peserta didik untuk mencapai KKM (Kriteria Ketuntasan Minimal) yang digunakan sebagai tolok ukur pembelajaran yang sudah ditetapkan sebelumnya. Sehingga pembelajaran dapat dikatakan tuntas. Untuk melihat hasil ketuntasan tes keterampilan bercerita peserta didik dapat dilihat dalam diagram ketuntasan klasikal dibawah ini.

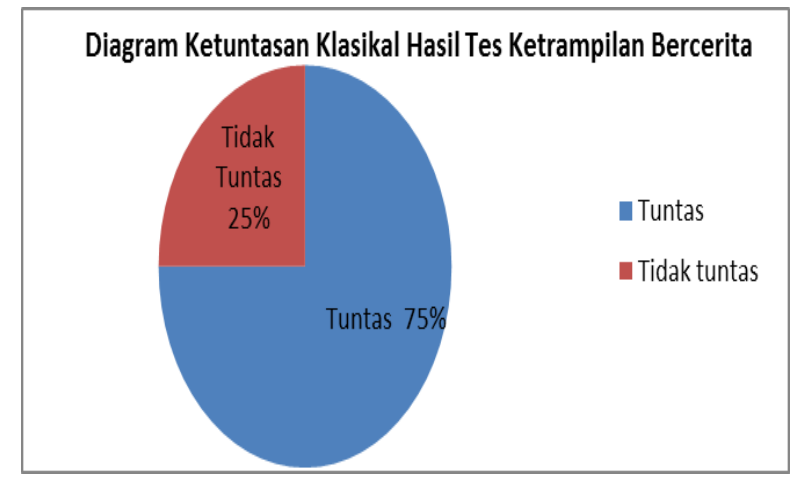

Gambar 1. Diagram Ketuntasan Klasikal Hasil Tes Keterampilan Bercerita Peserta didik

Diagram tersebut menunjukkan ketuntasan klasikal tes keterampilan bercerita muatan peajaran bahasa indonesia. Diperoleh ketuntasan klasikal sebanyak 75\% dan ketidak tuntasan sebanyak 25\% . dari hasil tersebut dapat disimpulkan bahwa dari keseluruhan peserta didik kelas III C sebanyak 32 peserta 
didik, yang mampu mencapai KKM sebanyak 24 Peserta didik sedangkan sisanya hanya 8 peserta didik yang tidak mampu mencapai KKM yag telah ditetapkan. Berdasarkan data mengenai hasil tes keterampilan bercerita pada bidang pelajaran bahasa indonesia telah ditetapkan tuntas. Hal ini ditetapkan karena didapatkanya persentase klasikal kategori "Baik" dengan jumlah 32 Peserta didik dan hanya 8 peserta didik yang tidak tuntas.

Hasil respon peserta didik saat implementasi membaca kreatif dalam keterampilan bercerita membentuk respon positif. Diperoleh persentase peserta didik sebesar 91\% yang diikuti 32 peserta didik menunjukkan bahwa dengan penerapan membaca kreatif sehingga memudahkan saat pembelajaran bercerita. Respon peserta didik dapat ditunjukkan dengan diagaram keterlaksanaan tiap indikator dibawah ini.

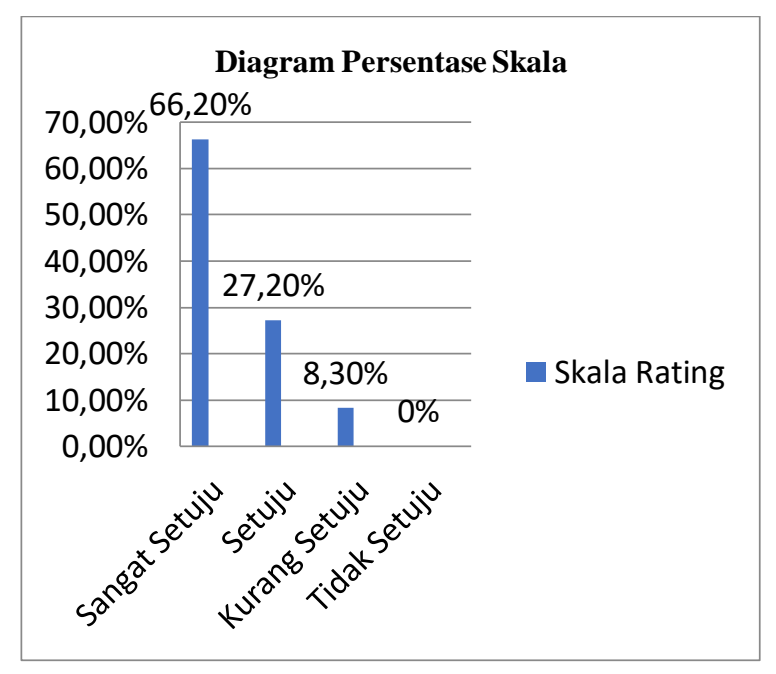

Gambar 2. Diagram persentase skala respon minat peserta didik

Sehingga dapat disimpulkan bahwa membaca kreatif dalam keterampilan bercerita yang diimplementasikan saat tahap pembelajaran mampu dipahami peserta dengan baik dan memberi manfaat solusi terbaik memahami dan mengingat cerita dengan baik oleh peserta didik.

\section{KESIMPULAN}

Bersumber dari riset diperoleh data mengenai "Penerapan Membaca Kreatif Dalam Keterampilan Bercerita Tema 4 Subtema 1 Pembelajaran 2 kelas III SDN Sedati Gede II Sidoarjo tahun pelajaran 2019/2020." Dapat disimpulkan seperti berikut: 1) Proses penerapan membaca kreatif dalam keterampilan bercerita tahun pelajaran 2019/2020 terlaksana degan kategori sangat baik. Hampir semua kegiatan dilakukan pendidik dan peserta didik, Sesuai dengan sintaks yang ditulis sehingga tercipta pembelajaran yang menjadikan seluruh peserta didik aktif dan mendapatkan kesempatan yang sama untuk mengembangkan ide dan kreatifitas dalam mengarang suatu cerita. 2) Hasil penerapan membaca kreatif dalam keterampilan bercerita tema 4 tahun pelajaran 2019/2020 memperoleh hasil akhir yang memuaskan dengan kategori "Baik" dan respon yang positif dari peserta didik. Pernyataan tersebut dilandaskan dari 
tes keterampilan bercerita dan angket respon. a) Tes keterampilan bercerita diperoleh nilai dan ketuntasan klasikan dengan kategori Baik. b) Hasil respon peserta didik diperoleh dengan kategori Baik.

\section{DAFTAR PUSTAKA}

Aisyah, Siti. 2007. Perkembangan Anak Usia Dini. Jakarta: Universitas Pendidikan Indonesia

Aqib. 2017. Model Media Strategi Pembelajaran. Yogyakarta:Ar-Ruzz Media.

Arifin, Zainal. 2014. Evaluasi Pembelajaran. Jakarta: PT. Rosda Karya.

Arikunto, Suharsimi. 2014. Dasar-Dasar Evaluasi Pendidikan. PT. Rineka Cipta.

Bachir. Bachtiar S. 2005. Pengembangan Bercerita di Taman Kanak-Kanak. Jakarta: Departemen Pendidikan Nasional.

Dalman. 2014. Keterampilan membaca. Jakarta: PT. Raja Grafindo Persada

Daryanto. 2009. Panduan Penyusunan Kurikulum Tingkat Satuan Pendidikan Jenjang Pendidikan Sekolah Dasar Menengah. Jakarta:BSNP.

Hartati. 2003. Pendidikan Bahasa dan Sastra Indonesia Kelas Rendah. Bandung:Upipress.

Kemendikbud. 2018. Buku Tematik Terpadu Kurikulum 2013 kelas III Tema 4 (Buku Guru). Jakarta: kemendikbud.

Machsunah, S. 2014. Keterampilan Bercerita. Malang: Genius Media.

Rachmadtullah, Reza, Via Yustitia, Bramianto Setiawan, Arif Mahya Fanny, Pana Pramulia, Wahyu Susiloningsih, Cholifah Tur Rosidah, Danang Prastyo, and Trio Ardhian. 2020. "The Challenge Of Elementary School Teachers To Encounter Superior Generation In The 4.0 Industrial Revolution: Study Literature." International Journal of Scientific \& Technology Research 9(4):1879-82.

Sari, Yunita, Ratri Dyah Luvita, Andarini Permata Cahyaningtyas, Vina Iasha, and Bramianto Setiawan. 2020. "Pengaruh Metode Pembelajaran Struktural Analitik Sitentik Terhadap Kemampuan Menulis Permulaan Di Sekolah Dasar." Jurnal Basicedu 4(4):1125-33. 